\title{
The application and testing of diatom-based indices in the Vaal and Wilge Rivers, South Africa
}

\author{
JC Taylor*, MS Janse van Vuuren and AJH Pieterse \\ School of Environmental Sciences and Development, Potchefstroom Campus of the North-West University, \\ Potchefstroom 2520, South Africa
}

\begin{abstract}
Chemical monitoring of water resources is time-consuming and comparatively expensive and may not always provide a composite reflection of actual water quality. Biotic indices using faunal elements, such as macroinvertebrates and fish, are already in place in South Africa as part of the National Biomonitoring Programme for Aquatic Ecosystems (NBPAE). As yet periphyton communities are not included in this programme due to perceived difficulties in the application of these methods. Diatom samples were collected from 10 sites in the Vaal and Wilge Rivers for a period of one year. Diatom cells from these communities were enumerated and diatom-based indices were calculated using OMNIDIA v.3. Diatom index scores were correlated to physical and chemical water quality variables over different time periods and at different concentrations. It was found that the tested diatom indices in general have the best correlation with average chemical data for a one-month period, starting six weeks prior to biological sampling. The Biological Diatom Index showed the strongest relationship to general water quality, while the Eutrophication and Pollution Index showed the strongest relationship to dissolved inorganic phosphorus. Results of correlation analyses obtained in South Africa were comparable to those obtained in several European studies. Hence, it is concluded that diatom-based indices, if implemented in South Africa, will provide a valuable addition to South Africa's suite of tools for the biological monitoring of water quality.
\end{abstract}

Keywords: diatoms, water quality, indices, Vaal River, Wilge River

\section{Introduction}

The assessment of the general quality of a water resource requires regular monitoring. Chemicals and chemical compounds constantly fluctuate in the river system; they are broken down, and dissolved by environmental conditions such as light and heat energy, they are also constantly removed from the system via uptake by organisms and sedimentation. Chemical components in a river system may also be diluted by inflows of rainwater or augmented from runoff from point (mine, sewage, storm water drainage) and diffuse sources (agricultural runoff, groundwater seepage from settling ponds), or become concentrated during times of drought and low flow. These factors make it difficult, if not impossible, to provide anything other than a fragmented overview of the state of a river along its complete length using conventional chemical monitoring techniques. Rapid efficient and cost-effective techniques, such as diatom-based pollution indices, are therefore required for the routine monitoring of rivers.

The monitoring of South African waterways has traditionally been carried out by two means, firstly by chemical analysis determining the water quality, and more recently by the use of various biomonitoring techniques such as the South African Scoring System (SASS) and the Fish Health Index (FHI). These techniques were introduced as part of routine monitoring programmes due to certain shortcomings in standard physical and chemical methods. These monitoring techniques form part of the National Biomonitoring Programme for Aquatic Ecosystems (NBPAE; Hohls, 1996). It has become important to use various methods as alternatives to chemical analyses as these techniques

* To whom all correspondence should be addressed.

喕 +2718299 4305; fax: +27 182992503 ;

e-mail: Jonathan.Taylor@nwu.ac.za

Received 4 January 2006; accepted in revised form 28 October 2006. provide, at best, a fragmented overview of the state of a river as sporadic or periodic sampling cannot reflect, e.g. fluxes of effluent discharge, dumping or storm events. In contrast, the community structure of a given group of riverine organisms will be shaped by the chemical and physical nature of their habitat. Changes in water chemistry will inhibit the multiplication of some of the species originally present, and encourage that of others, so that primarily the association, i.e. the percentage composition of certain species within a community will be changed (Cholnoky, 1960). These changes in species composition can in turn be used to reflect changes in water quality in a more integrated manner than traditional chemical sampling.

The potential of diatoms as indicators of water quality was realised early on in South Africa by Cholnoky (1968), Archibald (1972), Schoeman (1976) and Schoeman (1979). Schoeman (1979) tested Lange-Bertalot's (1979) method in the upper Hennops River and found the method successful, with a good correlation between the species composition of the diatom communities studied, and the water quality. Diatoms, as indicators of water quality, were only again investigated in depth in South Africa by Bate et al. (2002). They came to the conclusion that benthic diatoms could be a useful addition to the NBPAE as the diatoms give a time-integrated indication of specific water quality components. However, Bate and co-workers went on to state that the particular data set tested in their study (that of Van Dam et al., 1994), could not be transposed directly for use under South African conditions. For this reason the present study has investigated the potential use of several other diatom indices in the Vaal River system as part of a national investigation into the efficacy of these indices for use in bio-monitoring of South African rivers

It is generally accepted that invertebrate-based indices do not provide a reliable indication of eutrophication and for this reason it is better to take direct measurements of the photo- 


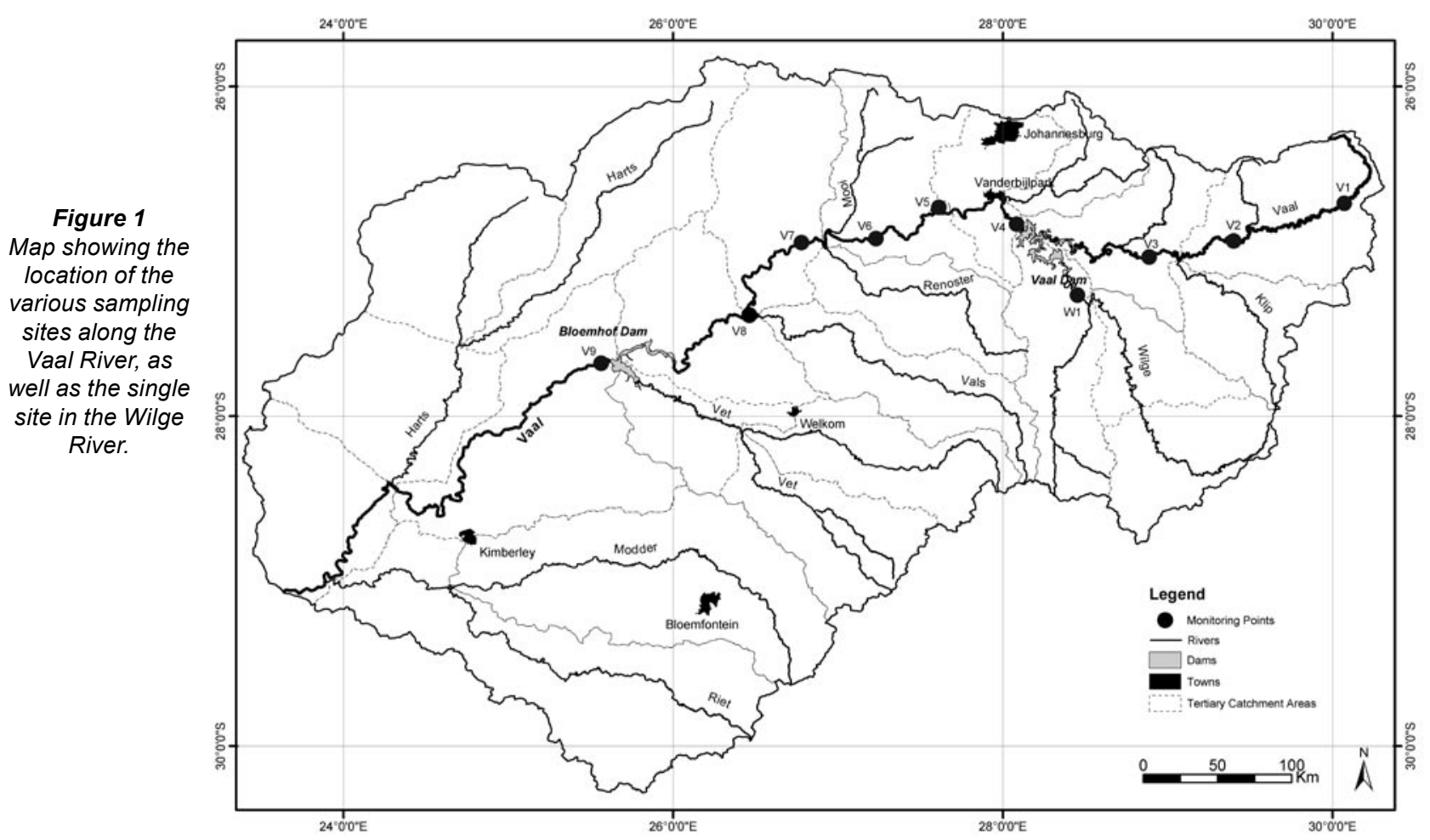

synthetic community (Kelly, 1998). Diatoms are the preferred organisms used in bio-monitoring of eutrophication. Algae actively assimilate plant nutrients for growth and reproduction. Diatoms, which constitute $40 \%$ of any given algal community (Round et al., 1990), provide a representative group of species indicative of the effects of a particular concentration of plant nutrients on riverine 'health'.

In Europe a concerted effort is being made to standardise the routine sampling and processing of diatoms for water quality assessments (Kelly et al., 1998; Prygiel et al., 2002). The various diatom indices fall into different classes. A discussion of each class relevant to the present study and representative index(s) may be found in Taylor (2004). A discussion of the manner in which diatom indices function may be found in Harding et al. (2005).

When diatom indices are applied outside of the region of origin, strict testing is required to ensure that diatom index scores give a realistic reflection of the specific type of environmental pollution being tested. As water flows past fixed plant growth, historical physico-chemical data (collected at least two weeks prior to sampling) are regarded as ideal by Bate et al. (2002) for the basis of comparing diatom community structure and water quality, if the flow regime has not been altered in that period. Prygiel and Coste (1993) found that the best correlations are noted with chemical analysis carried out just before sampling. Hence, for an accurate comparison of diatom indices and water quality, the present study has critically examined one-off chemical water quality data collected both prior and concurrently with diatom sampling (as in Prygiel and Coste, 1993). The average chemical data for a period of one month ending two weeks before sampling for diatom communities and the average chemical data for a period of one month ending six weeks before sampling for diatom communities have been used for comparative purposes.

A further difficulty when relating diatom index scores to actual chemical conditions is encountered when considering the reaction of diatom communities to differing concentrations and peaks in water quality variables. Chutter (1998), in a discussion

of the effects of water quality variables on macro-invertebrates, is of the opinion that extreme physical and chemical conditions govern the biology of the stream. Bate et al. (2004a) pose the question as to whether diatoms in a system react to a high value of mineral element(s) or 'spikes' in the system. For this reason comparisons between the results of chemical analysis and the structure of diatom communities were carried out on several differing data sets for the same periods of time, in addition to both average data and available data on extreme conditions or 'spikes'.

This study aimed to dispel some of the misconceptions surrounding water quality monitoring using diatom pollution indices. Diatom index scores were calculated and correlated to water quality variables. The results of these correlation analyses were compared to results obtained in similar studies carried out in Europe. In addition it was determined whether diatoms reflect the influence of average concentrations of a particular water quality variable (i.e. their response to pollution is integrative), or whether the diatoms react to the maximum concentrations of water quality variables passing through the system.

\section{Materials and methods}

\section{Diatom sampling, preparation and analysis}

Diatoms were sampled monthly at each of the sites for the period March 2002 to February 2003 at the sites indicated in Fig. 1.

All diatom samples were removed from three or more boulders $(>256 \mathrm{~mm})$ where possible. Rocks were collected close to the riverbank, in riffles with flowing water. At some sites there were very few boulders and samples from these sites were very often collected from a single boulder (Kelly and Whitton, 1995). Boulders free from filamentous algae were chosen when possible. Boulders covered with a layer of sediment were also avoided. Dead wood was used as a substrate in the absence of boulders as suggested by Kelly et al. (1995).

Samples were taken at each site by scrubbing the substrate with a small brush and rinsing both the brush and the substrate 
with distilled water. The resulting diatom suspension was then poured into a $150 \mathrm{~m} \ell$ plastic sample bottle.

Diatom samples were prepared for light microscopy using acid oxidation techniques. These techniques, including the details of slide preparation and archiving, have been discussed in Taylor et al. (2005).

Counts of diatom valves on slides were made using a Zeiss microscope with phase contrast optics $(1000 \mathrm{x})$. A count of 300 to 500 valves per sample was used for data calculation, as recommended by Prygiel et al. (2002).

The flora of Krammer and Lange-Bertalot (1986-91) was used for identification of all species and for confirmation of species identification by other authors. Other taxonomic guides consulted include Schoeman and Archibald (1976-80), Round et al. (1990), Hartley et al. (1996) and Prygiel and Coste (2000). For revised nomenclature the works of Lange-Bertalot (2001), Krammer (2002) and Kellogg and Kellogg (2002) were consulted.

\section{Diatom index calculation}

The indices used here are known as Descy's index or DES (Descy, 1979), the Generic Diatom Index or GDI (Coste and Ayphassorho, 1991), the Specific Pollution Sensitivity Index or SPI (Coste in CEMAGREF, 1982), the Biological Diatom Index or BDI (Lenoir and Coste, 1996), the Artois-Picardie Diatom Index or APDI (Prygiel et al., 1996), Sládeček's index or SLA (Sládeček, 1986), the Eutrophication/Pollution Index or EPI (Dell'Uomo, 1996), Leclercq and Maquet's Index or LMI (Leclercq and Maquet, 1987), the Commission of Economical Community Index or CEC (Descy and Coste, 1991) Schiefele and Schreiner's Index or SHE (Schiefele and Schreiner, 1991), the Trophic Diatom Index or TDI (Kelly and Whitton, 1995), and the Watanabe Index or WAT (Watanabe et al., 1986; Watanabe, 1990). In all cases except in the CEC, SHE, TDI and WAT index, the diatom indices are calculated using the formula of Zelinka and Marvan (1961). For all of the above indices, except TDI (maximum value of 100), the maximum value of 5 (converted to 20 by the software package OMNIDIA; Lecointe et al., 1993) indicates pristine water.

Several chemical determinants were derived from the original data set. Dissolved inorganic nitrogen (DIN) was calculated from the summation of $\mathrm{NH}_{4}-\mathrm{N}, \mathrm{NO}_{3}-\mathrm{N}$ and $\mathrm{NO}_{2}-\mathrm{N}$. For the purpose of this study, the dissolved inorganic phosphorus (DIP) concentration was considered to be equivalent to the $\mathrm{PO}_{4}-\mathrm{P}$ concentration.

\section{Water quality}

$\mathrm{pH}$ values (using a Wissenchaftlich-Technische Werkstätten WTW Model pH 330/SET-1digital pH meter), turbidity values (using a Hach Company Model 2100P portable turbidity meter), oxygen concentrations and water temperatures (using a Yellow Springs YSI Model 54A oxygen/temperature meter) were measured simultaneously with biological sampling.

The Department of Water Affairs (DWAF) collected the water quality data used in this study as part of their National Chemical Monitoring Programme. Samples are collected weekly as part of this programme. The samples collected for this programme were analysed in the laboratories of the Resource Quality Services (RQS), Pretoria, and the data were stored on DWAF's database and information management system, namely the Water Management System (WMS). The environmental data used in this study were obtained from the WMS.

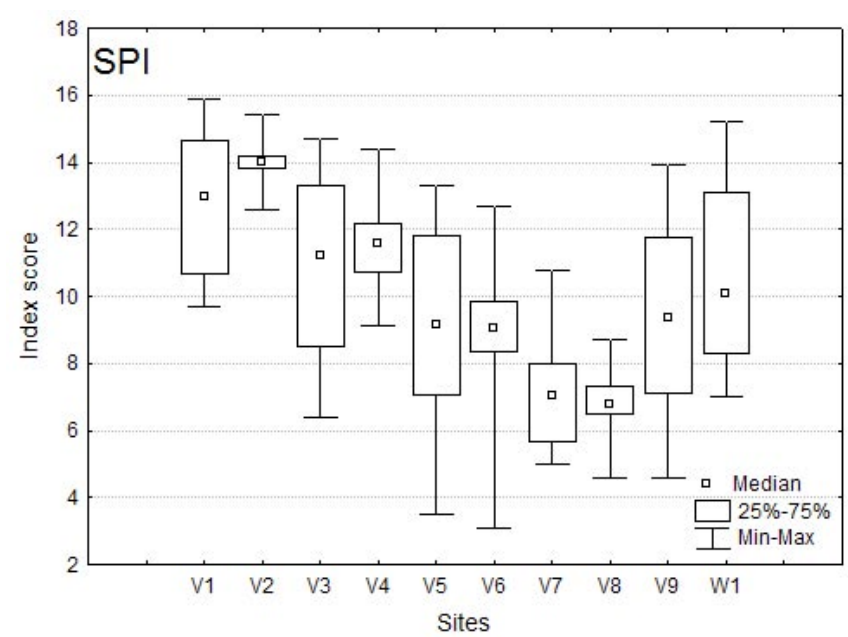

Figure 2

Box plot of median annual values for Specific Pollution sensitivity Index (SPI) in the Vaal and Wilge Rivers for the period of 1 year. V1 = Bloukop, V2 = Downstream of Grootdraai Dam

V3 = Gladdedrift, V4 = Downstream Vaal Dam, V5 = Goose Bay

Estates downstream of Vaal Barrage, V6 $=$ Schoemansdrift,

V7 = Orkney, V8 = Klipplaatdrift, V9 = Downstream of

Bloemhof Dam, W1 = Wilge River at Frankfort.

\section{Results and discussion}

\section{Species composition}

During the course of the study 245 diatom taxa were encountered, comprising 54 genera. A full species list of the taxa encountered (including all synonyms) is given in Taylor (2004). Sixty-nine of the 245 taxa encountered were recorded as dominant (i.e. occurring as $>5 \%$ of any given community) and they are illustrated with light micrographs in Taylor (2004).

Concern has been expressed as to the feasibility of transferring data concerning the ecological tolerance limits of diatoms between the Northern and Southern Hemispheres (Round, 1991; Kelly et al., 1998). However, if the species composition of the samples is examined, it is found that of the 69 dominant taxa, only two are endemic to Southern Africa (Navigiolum adamantiforme (Archibald) Taylor \& Lange-Bertalot and Eolimna archibaldii Taylor \& Lange-Bertalot). The remaining 67 dominant taxa are, without doubt, cosmopolitan species well-documented in international literature (e.g. Krammer and Lange-Bertalot, 1986-1991). Of the 176 nondominant taxa encountered, a further three taxa are possibly endemic to Southern Africa namely Navicula microrhombus Archibald, Thalassiosira duostra Pienaar \& Pieterse and a species as yet not identified leaving a total of 240 out of 245 (98\%) cosmopolitan taxa (i.e. taxa encountered both in Europe and South Africa). These results are in agreement with Bate et al. (2004b) who found that most dominant diatom species found in South African rivers were already recorded in international literature.

\section{Diatom index scores}

A selection of the tested diatom indices were chosen with the aim of representing the degree of aquatic pollution at each of the study sites in the Vaal and Wilge Rivers. The indices chosen for the representation of water quality are the SPI (Fig. 2), BDI 


\begin{tabular}{|c|c|c|}
\hline \multicolumn{3}{|c|}{$\begin{array}{c}\text { TABLE 1 } \\
\text { Class limit values for diatom indices } \\
\text { (Eloranta \& Soininen, 2002) }\end{array}$} \\
\hline Index score & Class & Trophy \\
\hline$>17$ & high quality & oligotrophy \\
\hline 15 to 17 & good quality & oligo-mesotrophy \\
\hline 12 to 15 & moderate quality & mesotrophy \\
\hline 9 to 12 & poor quality & meso-eutrophy \\
\hline$<9$ & bad quality & eutrophy \\
\hline
\end{tabular}

(Fig. 3), GDI (Fig. 4), and the EPI (Fig. 5). SPI was chosen as it has the broadest species base; BDI showed the best overall correlation to water quality variables, GDI functions at a genus level of identification and is hence the simplest index to use. The EPI showed the highest correlation to dissolved inorganic phosphate.

Diatom index scores range between 0 and 20, a decreasing score indicating an increasing level of pollution or eutrophication. Class limit values were imposed on diatom index scores for SPI and GDI to indicate levels of pollution in Finland (Eloranta and Soininen, 2002). These values (Table 1) were used in this study for the interpretation of the scores yielded by the various indices.

All of the graphs in Figs. 2 to 5, with the exception of the graph for EPI, display a steady downward trend in water quality over distance up to point V8 at Balkfontein before the Vaal River flows into the Bloemhof Dam. This decline is interrupted at the sites of major dams. Water quality increases slightly, immediately downstream of large dams due to consumption and sedimentation of major nutrients and ions within the dam. These improvements are most noticeable at V4 below the Vaal Dam and V9 below Bloemhof Dam and in some indices at V2 below the Grootdraai Dam.

The EPI (Fig. 5) demonstrates a different trend than the other indices. A steady improvement can be seen from site V6 at Orkney to V8 at Kliplaatdrift. This may be directly ascribed to the influence of plant nutrients (DIN and DIP), the concentration of which decreases from V6 to V8 and hence the concomitant increase in EPI score as it showed the highest correlation to dissolved inorganic phosphate (see discussion below).

\section{Correlation between diatom indices and concurrent physical and chemical water quality data}

Correlation analysis was performed between several water quality variables, collected concurrently or a few days prior to diatom sampling. Significant correlations were found between most of the diatom indices tested and water quality variables (see Table 3).

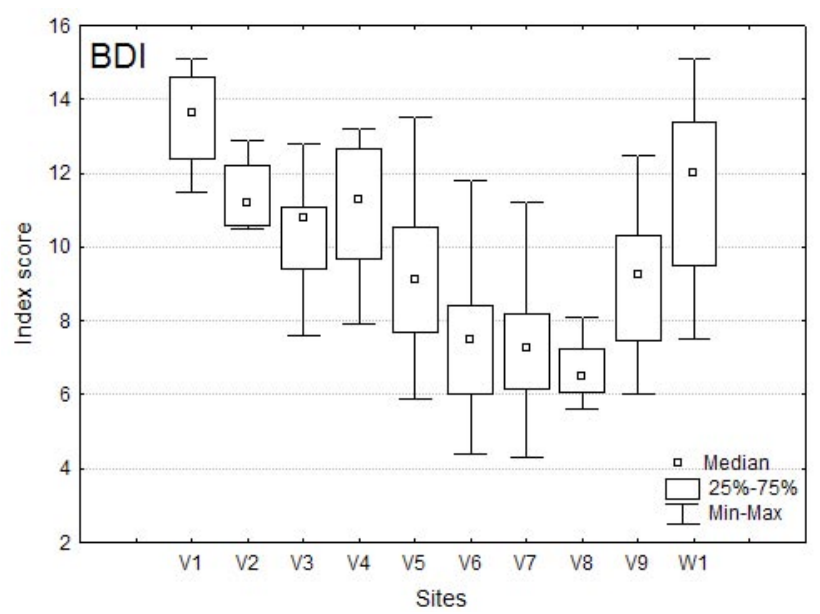

Figure 3

Box plot of median annual values for Biological Diatom Index $(B D I)$ in the Vaal and Wilge Rivers for the period of 1 year. Refer to Fig. 2 for site information.

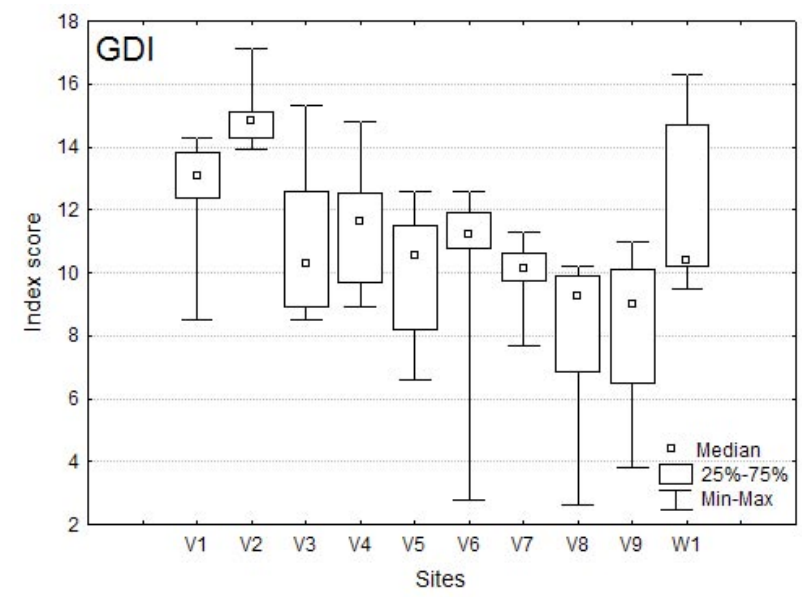

Figure 4

Box plot of median annual values for Generic Diatom Index $(G D I)$ in the Vaal and Wilge Rivers for the period of 1 year. Refer to Fig. 2 for site information.

\section{Correlation between diatom indices and water quality data averaged over one month}

The results for a correlation analysis performed between several elements of water quality and the selected diatom indices are presented in Table 4. The chemical data are the average for a period of one month ending two weeks before biological sampling (for experimental design see Table 2).

Data in Table 4 show that significant correlations exist between most of the diatom indices tested and average water quality variables. The elements of water quality that each index was designed to reflect, are boxed together in Table

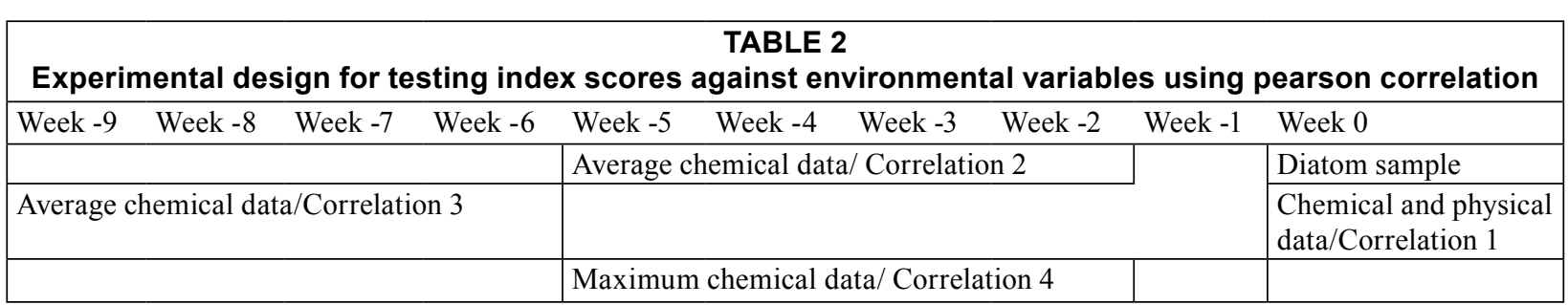




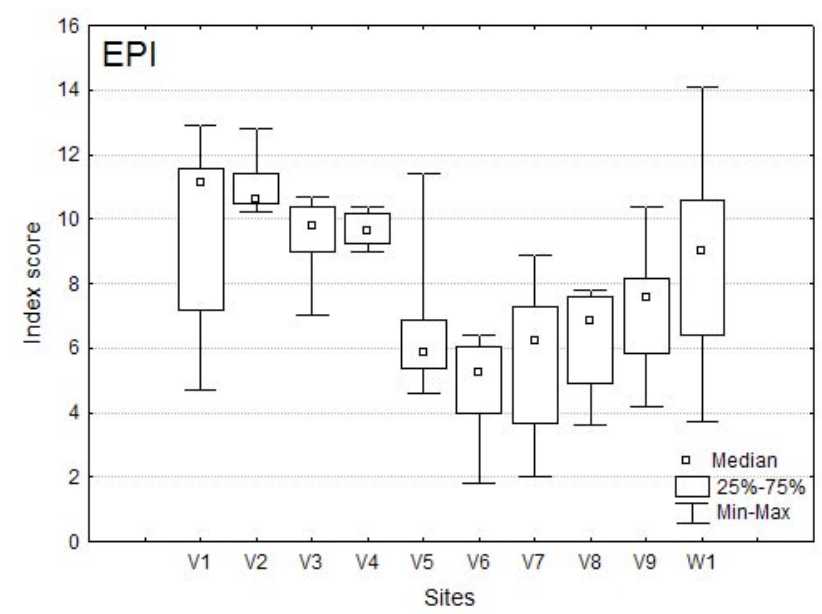

Figure 5

Box plot of median annual values for Eutrophication and Pollution Index (EPI) in the Vaal and Wilge Rivers.

Refer to Fig. 2 for site information.

4. In all cases these correlations were stronger than those demonstrated in the correlation to water quality undertaken concurrently with diatom sampling (see Table 3 ), and hence Table 4 will be used to discuss the reaction of diatom communities (as reflected by diatom index scores) to water quality variables.
The DES index shows the weakest correlation to general water quality. DES was developed in 1979 and was one of the first true autecological diatom indices of general water quality. Since the creation of DES, many other diatom indices have been developed with the aim of making diatom autecological indices more generally applicable across France and Europe (Prygiel and Coste, 1993). Most of the newer indices are in essence modifications of the DES index. The success of these modifications can be seen in the SPI and the BDI.

The SLA index correlates significantly with all measured variables of water quality (see Table 4). The SLA, based on $\mathrm{BOD}_{5}$ measurements, was developed to provide a reflection of the organic pollution present within a certain aquatic ecosystem. Compounds of nitrogen and phosphorus are often present in high concentrations in organic discharges. The partial degradation of proteins and other nitrogenous material can lead to elevated ammonia, nitrite and nitrate concentrations and may account for the significant correlations between SLA and DIP and DIN (Table 4).

Silicate-silicon $\left(\mathrm{SiO}_{2}-\mathrm{Si}\right)$ is positively correlated to a number of the indices (see Table 4). $\mathrm{SiO}_{2}-\mathrm{Si}$ is an essential nutrient for the growth and reproduction of diatoms. However, it is important to note that, although the biomass of diatoms is limited by low $\mathrm{SiO}_{2}-\mathrm{Si}$ concentrations, limitation on growth has little influence on the relative abundance of prevalent diatom species in a sample (Gilpin et al., 2004). If low $\mathrm{SiO}_{2}$-Si concentrations did in fact affect the relative abundance of diatoms, then diatom

\begin{tabular}{|c|c|c|c|c|c|c|c|c|c|c|c|}
\hline & $\begin{array}{l}\text { Pears } \\
\text { :oncurre }\end{array}$ & $\begin{array}{l}\text { n corre } \\
\text { htly to } \\
\text { Numer }\end{array}$ & $\begin{array}{r}\text { tion co } \\
\text { atom sa } \\
\text { al valu } \\
n\end{array}$ & $\begin{array}{l}\text { fficien } \\
\text { ipling, } \\
\text { indic } \\
112 \text { (C) }\end{array}$ & $\begin{array}{l}\text { } \\
\text { betwe } \\
\text { ad diat } \\
\text { signi } \\
\text { wise }\end{array}$ & $\begin{array}{l}\text { 3LE } 3 \\
\text { water } \\
\text { n indic } \\
\text { ant co } \\
\text { etion }\end{array}$ & $\begin{array}{l}\text { ality } d \\
\text { at site } \\
\text { lations } \\
\text { missin }\end{array}$ & $\begin{array}{l}\text { a a fev } \\
\text { in the } \\
\text { t } p \leq 0 \\
\text { data) }\end{array}$ & $\begin{array}{l}\text { days } p \\
\text { aal an } \\
1 \text { or hi }\end{array}$ & $\begin{array}{l}\text { ously } \\
\text { ilge Ri } \\
\text { r }\end{array}$ & \\
\hline & SPI & SLA & DES & LMI & SHE & WAT & GDI & CEC & BDI & APDI & EPI \\
\hline $\mathrm{pH}$ &.. &.. &.. &.. &.. &.. &.. & -0.32 & -0.35 & -0.25 &.. \\
\hline TAL & -0.31 & -0.24 & .. & -0.28 & .. & -0.29 & -0.28 & -0.33 & -0.44 & -0.28 & -0.19 \\
\hline DIP & -0.42 & -0.48 & -0.25 & -0.45 & -0.26 & -0.37 &.. & -0.48 & -0.36 & -0.33 & -0.52 \\
\hline DIN &.. & -0.28 &.. &.. &.. &.. &.. &.. &.. &.. &.. \\
\hline $\mathrm{EC}$ & -0.50 & -0.48 &.. & -0.48 & .. & -0.46 & -0.37 & -0.52 & -0.63 & -0.42 & -0.44 \\
\hline $\mathrm{DO}_{2}$ &.. &.. &.. &.. &.. & .. &.. &.. &.. &.. &.. \\
\hline Temp. & -0.35 &.. & -0.27 &.. & -0.29 & -0.51 & -0.29 & -0.27 &.. &.. & -0.36 \\
\hline Turb. & .. & 0.31 &.. & 0.25 & .. & .. &.. &.. & 0.32 &.. & .. \\
\hline
\end{tabular}

\begin{tabular}{|c|c|c|c|c|c|c|c|c|c|c|c|}
\hline \multicolumn{12}{|c|}{$\begin{array}{c}\text { TABLE } 4 \\
\begin{array}{c}\text { Pearson correlation coefficients between some average water chemistry variables and diatom indi- } \\
\text { ces at sites in the Vaal and Wilge Rivers. } \\
\text { Numerical values indicate significant correlations at } p \leq 0.01 \text { or higher } \\
n=112 \text { (Casewise deletion of missing data) }\end{array}\end{array}$} \\
\hline & SPI & SLA & DES & LMI & SHE & WAT & GDI & CEC & BDI & APDI & EPI \\
\hline $\mathrm{pH}$ & -0.29 & -0.37 & .. & -0.34 & .. & .. & & -0.34 & -0.47 & -0.43 & .. \\
\hline TAL & -0.36 & -0.27 & .. & -0.34 & .. & -0.32 & -0.34 & -0.40 & -0.49 & -0.34 & \\
\hline DIP & -0.53 & -0.51 & -0.36 & -0.49 & -0.37 & -0.50 & -0.32 & -0.61 & -0.43 & -0.33 & -0.60 \\
\hline DIN & -0.26 & -0.42 & .. & -0.31 & -0.26 & .. &.. & -0.27 & .. &.. & -0.33 \\
\hline $\mathrm{EC}$ & -0.52 & -0.50 & -0.22 & -0.50 & -0.29 & -0.48 & -0.39 & -0.59 & -0.64 & -0.47 & -0.47 \\
\hline $\mathrm{SiO}_{2}-\mathrm{S}$ & .. & 0.33 & .. & 0.30 & .. & 0.28 & 0.15 & 0.29 & 0.48 & 0.35 & \\
\hline
\end{tabular}


index scores would be skewed as a result of $\mathrm{SiO}_{2}-\mathrm{Si}$ limitation in aquatic ecosystems.

\section{Correlation between diatom indices and maximum concentration of recent water quality variables}

The results of a correlation between several diatom indices and the maximum concentration of chemical elements of water quality are presented in Table 5 . The chemical data used represent the maximum values (single figures) encountered during the period of one month ending two weeks before biological sampling.

A difference test specifically for correlation coefficients was used to evaluate the significance of differences between the results shown in Tables 3 and 5. The outcome of the difference test depends not only on the size of the raw difference between the two coefficients, but also on the size of the samples and on the size of the coefficients themselves (StatSoft Inc., 2003).

Data in Table 5 compared to those given in Table 3, for all chemical variables, with the exception of $\mathrm{pH}$ and total alkalinity (TAL), show that correlation coefficients obtained in both tables are similar, i.e. there is no statistically significant differences between the correlation coefficients $(p \leq 0.01)$. In Table 5 it is shown that peaks or spikes in $\mathrm{pH}$ values may alter the diatom community, as reflected in the diatom index scores, rather than the average values. The WAT index shows a significant correlation to the maximum values for $\mathrm{pH}$, but no significant correlation to average $\mathrm{pH}$ values. The SLA index and the LMI also both demonstrate closer correlation to maximum values for $\mathrm{pH}$ rather than average values. It should however be noted that the correlation coefficients for the SLA and LMI and $\mathrm{pH}$ in Table 1 and 2 are not significantly different $(\mathrm{p}<0.01)$. A possible reason why diatom communities react to 'peaks' or 'spikes' in $\mathrm{pH}$ may be that diatoms are very sensitive to $\mathrm{pH}$ levels and have well- defined, and in some cases narrow, tolerance limits to this water quality variable (Cholnoky, 1968).

\section{Correlation between diatom indices and average wa- ter quality data six weeks prior to biological sampling}

The results of a correlation between diatom indices and chemical elements of previous water quality are presented in Table 6 . The chemical data used in the correlation are the average for a period of one month ending six weeks before biological sampling was carried out. The correlation presented in Table 3 was carried out with the aim of determining if a diatom community reflects the water quality of 6 weeks past rather than four.

There is no significant difference between correlation coefficients $(\mathrm{p}<0.01)$ as displayed in Table 6 data compared with data of most chemical variables in Table 4 . The similarity between the correlation results, presented in Tables 4 and 6 is probably due to the nature of the Vaal River. It is mostly broad and slow flowing and hence relatively stable. Therefore, the diatom indices reflect an integration of the water quality variables to which they have been exposed over a period of six to eight weeks in this particular river system. It should be stressed, however, that this may not always be the case in shallower, faster flowing streams subject to point source impacts. It should be noted that the BDI (boxed) has the most stable correlation over time, i.e. the correlation results from Tables 4 and 6 are almost identical, with the exception of the correlation co-efficient for DIN.

\section{Comparing correlation results with those of European studies}

Although diatom indices correlated well with the water quality variables measured in the present study, it is necessary to com-

\begin{tabular}{|c|c|c|c|c|c|c|c|c|c|c|c|}
\hline \multicolumn{12}{|c|}{$\begin{array}{l}\text { TABLE } 5 \\
\text { Pearson correlation coefficients between the maximum values for some water chemistry variables } \\
\text { and diatom indices at sites in the Vaal and Wilge Rivers. } \\
\text { Numerical values indicate significant correlations at } p \leq 0.01 \text { or higher } \\
n=113 \text { (Casewise deletion of missing data). }\end{array}$} \\
\hline & SPI & SLA & DES & LMI & SHE & WAT & GDI & CEC & BDI & APDI & EPI \\
\hline $\mathrm{pH}$ & -0.29 & -0.41 &.. & -0.40 &.. & -0.24 &.. & -0.36 & -0.47 & -0.47 &.. \\
\hline TAL & -0.35 & -0.26 & .. & -0.32 & .. & -0.33 & -0.32 & -0.40 & -0.45 & -0.36 & -0.25 \\
\hline DIP & -0.46 & -0.46 & -0.28 & -0.42 & -0.30 & -0.45 & -0.25 & -0.53 & -0.37 & -0.30 & -0.56 \\
\hline DIN &.. & -0.42 &.. & -0.26 &.. & .. &.. &.. &.. &.. & -0.33 \\
\hline $\mathrm{SiO}_{2}-\mathrm{S}$ & .. &.. & .. & .. &.. & .. &.. &.. & 0.32 &.. & .. \\
\hline EC & -0.53 & -0.52 &.. & -0.51 & -0.29 & -0.50 & -0.39 & -0.61 & -0.62 & -0.48 & -0.50 \\
\hline
\end{tabular}

\begin{tabular}{l} 
Tearson correlation coefficients between the average values for some water chemistry variables, \\
collected $\mathbf{6}$ weeks prior to biological sampling, and diatom indices at sites in the Vaal and Wilge Rivers. \\
Numerical values indicate significant correlations at p $\mathbf{0 . 0 1}$ or higher \\
$\boldsymbol{n = 1 1 3}$ (Casewise deletion of missing data). \\
\hline
\end{tabular}


pare these correlations with correlations demonstrated in similar studies in Europe. The data in Table 7 are presented with the aim of indicating the degree to which the results obtained during different studies in Europe are comparable with the results obtained in the present study of two South African rivers.

Other than the DES index, it can be seen that the correlation results between indices and water quality variables obtained in the present study are comparable and in some cases better than the correlations demonstrated in Europe. The same method used to evaluate the difference between the correlation coefficients in the previous section, was used to determine if there are any significant difference between correlation coefficients demonstrated by European authors and those demonstrated in the present study.

\section{Regression analysis}

The multiple regression method was used by Lenoir and Coste (1996) to demonstrate the relationship between several diatom indices and a combination of water quality variables. Regression analysis was used in the present study to determine which of the indices gave the best overall, i.e. integrative, reflection of general water quality. The regression method used is known as forward stepwise regression.

Figure 6 demonstrates the levels of success of the BDI in indicating a suite of water quality variables. The degree of confidence in the indices is reflected by the $\mathrm{r}^{2}$ value; the higher the value, the more accurate the indices are as integrative indicators of the measured water quality variables. The measured water quality variables account for $60 \%$ of the variation in the BDI scores. Of all the indices tested in this manner the BDI index most successfully indicates general water quality.

During the development of the BDI in France by Lenoir and Coste (1996) it was shown that the overall water quality analysis explained $72 \%$ of the variation in the BDI. Lenoir and Coste (1996) believed that the limit for the performance of an index is obtained by using the BDI and that the additional $30 \%$ in the specific scoring of the index would need to be explained by variability due to environmental factors not taken into account during the calculation of the index score. These factors include light, water flow (current speed), mineralisation and the nature of the substratum. From the results of the present study, in which $60 \%$ of the variation in BDI scores can be explained by measured environmental variables, it can be concluded that this index is both applicable and useful for monitoring water quality in the Vaal and Wilge Rivers.

\section{Conclusions}

The results of this study show that not only do the diatom communities, when analysed, provide an accurate assessment of water quality, but these diatom communities also provide an integrated reflection of past water quality. Community composition in the Vaal River best reflects the average water quality variables measured two weeks before sampling, as well as average water quality variables measured six weeks before sampling. Although there was significant correlation between concurrent chemical samples and diatom indices, there is a much stronger relationship between average water quality and diatom indices, and from this it may be concluded that diatoms provide an integrated reflection of general water quality.

The results of the present study show that, with the possible exception of $\mathrm{pH}$, diatom communities do not react to peaks in water quality variables. Spikes in $\mathrm{pH}$ would appear to determine

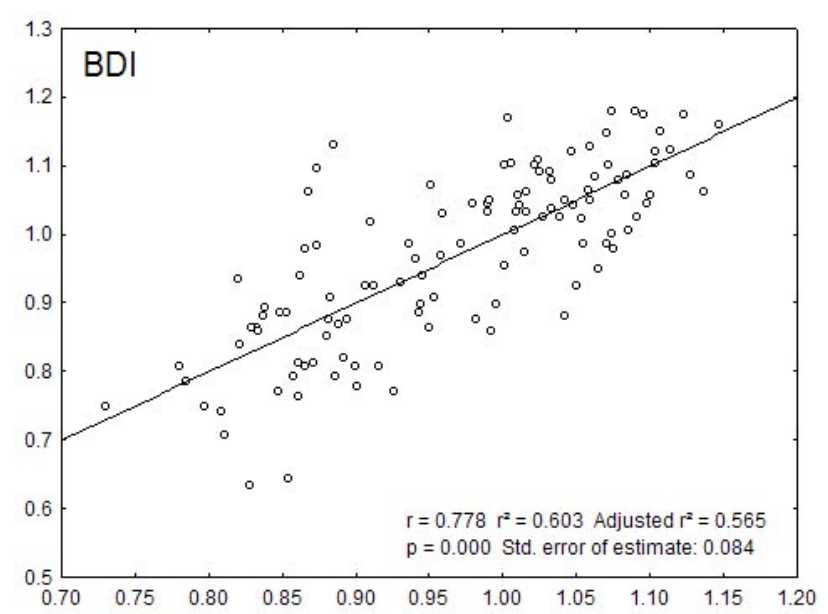

Figure 6

Predicted vs. observed values for Biological Diatom Index (BDI) in the Vaal and Wilge Rivers $(n=113)$

\begin{tabular}{|c|c|c|c|c|}
\hline \multicolumn{5}{|c|}{$\begin{array}{c}\text { TABLE } 7 \\
\text { Pearson correlation coefficients between average } \\
\text { water chemistry variables and diatom indices at } \\
\text { sites in the Vaal and Wilge Rivers as well as } \\
\text { comparative correlation data from some } \\
\text { European authors. } \\
\text { Numerical values indicate significant correlations } \\
\text { at } p \leq 0.01 \text { or higher. }\end{array}$} \\
\hline & & $\mathrm{pH}$ & DIP & EC \\
\hline \multirow[t]{9}{*}{ Present study } & SPI & -0.29 & -0.53 & -0.52 \\
\hline & SLA & -0.37 & -0.51 & -0.50 \\
\hline & DES &.. & -0.36 & -0.22 \\
\hline & LMI & -0.34 & -0.49 & -0.50 \\
\hline & SHE &.. & -0.37 & -0.29 \\
\hline & GDI &.. & -0.32 & -0.39 \\
\hline & $\mathrm{CEC}$ & -0.34 & -0.61 & -0.59 \\
\hline & BDI & -0.47 & -0.43 & -0.64 \\
\hline & APDI & -0.43 & -0.33 & -0.47 \\
\hline \multirow{8}{*}{$\begin{array}{l}\text { Kwandrans et } \\
\text { al. (1998) }\end{array}$} & SPI & \multirow{8}{*}{$\begin{array}{l}\text { No data } \\
\text { available }\end{array}$} & -0.51 & -0.75 \\
\hline & SLA & &.. & .. \\
\hline & DES & & -0.52 & -0.75 \\
\hline & LMI & & -0.57 & -0.69 \\
\hline & SHE & &.. & -0.71 \\
\hline & GDI & & -0.51 & -0.73 \\
\hline & CEC & & -0.62 & -0.69 \\
\hline & APDI & &.. & -0.56 \\
\hline \multirow{6}{*}{$\begin{array}{l}\text { Prygiel \& } \\
\text { Coste (1993) }\end{array}$} & SPI & 0.15 & 0.54 & 0.17 \\
\hline & SLA & 0.22 & 0.40 &.. \\
\hline & DES & 0.27 & 0.52 &.. \\
\hline & LMI & 0.22 & 0.52 &.. \\
\hline & GDI &.. & 0.40 & 0.21 \\
\hline & CEC & 0.16 & 0.50 & 0.19 \\
\hline \multirow{3}{*}{$\begin{array}{l}\text { Prygiel \& } \\
\text { Coste (1999) }\end{array}$} & SPI & 0.17 & 0.64 & 0.56 \\
\hline & BDI & 0.15 & 0.62 & 0.61 \\
\hline & APDI & 0.22 & 0.62 & 0.54 \\
\hline \multicolumn{5}{|c|}{ For abbreviations see Table 3} \\
\hline
\end{tabular}


diatom community composition rather than the average $\mathrm{pH}$ over a given period. However, this has not been demonstrated experimentally and requires further investigation.

The unique composite picture of ecosystem conditions provided by the diatoms can only be replicated by intensive chemical monitoring studies.

\section{Acknowledgments}

The authors would like to gratefully acknowledge Carin van Ginkel (RQS, DWAF) for her help in locating sampling sites and obtaining the chemical water quality data used in this project.

\section{References}

ARCHIBALD REM (1972) Diversity in some South African diatom associations and its relation to water quality. Water Res. 61229 1238.

BATE GC, ADAMS JB and VAN DER MOLEN JS (2002) Diatoms as Indicators of Water Quality in South African River Systems. WRC Report No 814/1/02. Water Research Commission, Pretoria.

BATE GC, SMAILES PA and ADAMS JB (2004a) Benthic Diatoms in the Rivers and Estuaries of South Africa. Vol. 1: Data Analysis. WRC Report No. 1107. Water Research Commission, Pretoria.

BATE GC, SMAILES PA and ADAMS JB (2004b) A water quality index for use with diatoms in the assessment of rivers. Water $S A$ 30 493-498.

CEMAGREF (1982) Etude des méthodes biologiques quantitatives d'appréciation de la qualité des eaux. Rapport Division Qualité des Eaux Lyon - Agence Financière de Bassin Rhône- MéditerranéeCorse. Pierre-Bénite.

CHOLNOKY BJ (1960) The relationship between algae and the chemistry of natural waters. CSA (Conseil Scientifique pour l'Afrique au Sud du Sahara). Specialist Meeting on Water Treatment. Com mission for Technical Co-operation in Africa South of the Sahara, Pretoria. Publication 64 215-225.

CHOLNOKY BJ (1968) Die Ökologie der Diatomeen in Binnengewässern. J Cramer, Lehre.

CHUTTER FM (1998) Research on the Rapid Biological Assessment of Water Quality Impacts in Streams and Rivers. WRC Report No 422/1/98. Water Research Commission, Pretoria.

COSTE M and AYPHASSORHO (1991) Étude de la qualité des eaux du Bassin Artois-Picardie à l'aide des communautés de diatomées benthiques (application des indices diatomiques). Rapport CEMAGREF. Bordeaux - Agence de l'Eau Artois-Picardie, Douai.

DELL'UOMO A (1996) Assessment of water quality of an Apennine river as a pilot study. In: Whitton BA and Rott (eds.) Use of Algae for Monitoring Rivers II. Institut für Botanik,Universität Innsbruck. $65-73$.

DESCY J-P (1979) A new approach to water quality estimation using diatoms. Nova Hedwigia 64 305-323.

DESCY J-P and COSTE M (1991) A test of methods for assessing water quality based on diatoms. Verh. Int. Verein. Limnol. 24 2112-2116.

ELORANTA P and SOININEN J (2002) Ecological status of Finnish rivers evaluated using benthic diatom communities. J. Appl. Phycol. 14 1-7.

GILPIN LC, DAVIDSON K and ROBERTS E (2004) The influence of changes in nitrogen: silicon ratios on diatom growth dynamics. J. Sea Res. 51 21-35.

HARDING WR, ARCHIBALD CGM and TAYLOR JC (2005) The relevance of diatoms for water quality assessment in South Africa: A position paper. Water $S A 31$ (1) 41-46.

HARTLEY B, BARBER HG, CARTER JR and SIMS PA (1996) An Atlas of British Diatoms. Biopress Ltd., Bristol.

HOHLS DR (1996) National Biomonitoring Programme for Riverine Ecosystems: Framework Document for the Programme. NBP Report Series No. 1. Institute for Water Quality Studies, Department of Water Affairs and Forestry, Pretoria.

KELLOGG B and KELLOGG DE (2002) Diatom Monographs. Vol. 1. Non-Marine and Littoral Diatoms from Antarctic and Subantarctic
Regions: Distribution and Updated Taxonomy. ARG Gantner Varlag, Kommanditgesellschaft, Ruggell.

KELLY MG (1998) Use of community-based indices to monitor eutrophication in European rivers. Environ. Conserv. 25 22-29.

KELLY MG, CAZAUBON A, CORING E, DELL'UOMO A, ECTOR L, GOLDSMITH B, GUASCH H, HÜRLIMANN J, JARLMAN A, KAWECKA B, KWANDRANS J, LAUGASTE R, LINSTRØM EA, LEITAO M, MARVAN P, PADISÁK J, PIPP E, PRYGIEL J, ROTT E, SABATER S, VAN DAM H and VIZINET J (1998) Recommendations for the routine sampling of diatoms for water quality assessments in Europe. J. Appl. Phycol. 10 215-224.

KELLY MG, PENNY CJ and WHITTON BA (1995) Comparative performance of benthic diatom indices used to assess river water quality. Hydrobiol. 302 179-188.

KELLY MG and WHITTON BA (1995) The trophic diatom index: A new index for monitoring eutrophication in rivers. J. Appl. Phycol. 7 433-444.

KRAMMER K (2002) Diatoms of Europe. Vol. 3 Diatoms of European Waters and Comparable Habitats. ARG Gantner Varlag Kommanditgesellschaft, Ruggell.

KRAMMER K and LANGE-BERTALOT H (1986-1991) Bacillariophyceae. 1-4. In: Ettl H, Gerloff J, Heynig H and Mollenhauer D (eds.) Süßwasserflora von Mitteleuropa Band 2. Spektrum Akademischer Verlag, Heidelberg, Berlin.

KWANDRANS J, ELORANTA P, KAWECKA B and W KRYZSYSZTOF (1998) Use of benthic diatom communities to evaluate water quality in rivers of southern Poland. J. Appl. Phycol. 10 193-201.

LANGE-BERTALOT H (1979) Pollution tolerance as a criterion for water quality estimation. Nova Hedwigia 64 285-304.

LANGE-BERTALOT H (2001) Diatoms of Europe. Vol. 2 Diatoms of European Waters and Comparable Habitats. ARG Gantner Varlag Kommanditgesellschaft, Ruggell.

LECLERCQ L and MAQUET B (1987) Deux nouveaux indices chimique et diatomique de qualité d'eau courante. Application au Samson et à ses affluents (bassin de la Meuse belge). Comparaison avec d'autres indices chimiques, biocénotiques et diatomiques. Institut Royal des Sciences Naturelles de Belgique, document de travail 28.

LECOINTE C, COSTE M and PRYGIEL J (1993) 'Omnidia': Software for taxonomy, calculation of diatom indices and inventories management. Hydrobiol. 269/270 509-513.

LENOIR A and COSTE M (1996) Development of a practical diatom index of overall water quality applicable to the French National Water Board network. In: Whitton BA and Rott E (eds.) Use of Algae for Monitoring Rivers II. Institut für Botanik, Universität Innsbruck. 29-43.

PRYGIEL J, CARPENTIER P, ALMEIDA S, COSTE M, DRUART JC, ECTOR L, GUILLARD D, HONERÉ MA, ISERENTANT R, LEDEGANCK P, LALANNE-CASSOU C, LESNIAK C, MERCIER I, MONCAUT P, NAZART M, NOUCHET N, PERES F, PEETERS V, RIMET F, RUMEAU A, SABATERS, STRAUB F, TORRISI M, TUDESQUE L, VAN DER VIJVER B, VIDAL H, VIZINET J, ZYDEK N. (2002) Determination of the biological diatom index (IBD NF T 90-354): Results of an intercomparison exercise. J. Appl. Phycol. 14 27-39.

PRYGIEL J and COSTE M (1993) The assessment of water quality in the Artois-Picardie water basin (France) by the use of diatom indices. Hydrobiol. 269/279 343-349.

PRYGIEL J and COSTE M (1999) Progress in the use of diatoms for monitoring rivers in France. In: Prygiel J, Whitton BA and Burkowska J (eds.) Use Of Algae for Monitoring Rivers III. Agence de l'Eau Artois- Picardie, France.

PRYGIEL J and COSTE M (2000) Guide méthodologique pour la mise en æuvre de l'indice Biologique Diatomées NF T 90-354. Agences de l'Eau-Cemagref de Bordeaux, mai 2000, 134 pages + Clés de déetrmination (89 planches) + cédérom français-anglais (tax'IBD)

PRYGIEL J, LÉVÊQUE L and ISERENTANT R (1996) Un nouvel indice diatomique pratique pour l'évaluation de la qualité des eaux en réseau de surveillance. Rev. Sci. Eau 1 97-113.

ROUND FE (1991) Diatoms in river water-monitoring studies. J. Appl. Phycol. 3 129-145.

ROUND FE, CRAWFORD RM and MANN DG (1990) The Diatoms: Biology and Morphology of the Genera. Cambridge University 
Press, Cambridge.

SCHIEFELE S and SCHREINER C (1991) Use of diatoms for monitoring nutrient enrichment acidification and impact salts in Germany and Austria. In: Whitton BA, Rott E and Friedrich G (eds.) Use of Algae for Monitoring Rivers. Institut für Botanik, Universität Innsbruck.

SCHOEMAN FR (1976) Diatom indicator groups in the assessment of water quality in the Jukskei-Crocodile river system (Transvaal, Republic of South Africa). J. Limnol. Soc. S. Afr. 2 (1) 21-24.

SCHOEMAN FR (1979) Diatoms as indicators of water quality in the upper Hennops River. J. Limnol. Soc. S. Afr. 5 (2) 73-78.

SCHOEMAN FR and ARCHIBALD REM (1976-80) The Diatom Flora of Southern Africa. National Institute for Water Research, Pretoria.

SLÀDEČEK V (1986) Diatoms as indicators of organic pollution. Acta Hydrochim. Hydrobiol. 14 (5) 555-566.

STATSOFT INC (2003) Basic Statistics. Online at http://www.statsoft com/textbook/stbasic.html. (Accessed on 04/03/2004).

TAYLOR JC (2004) The Application of Diatom-Based Pollution Indices in The Vaal Catchment. Unpublished M.Sc. Thesis, North-West
University, Potchefstroom Campus, Potchefstroom.

TAYLOR JC, DE LA REY PA and VAN RENSBURG L (2005) Recommendations for the collection, preparation and enumeration of diatoms from riverine habitats for water quality monitoring in South Africa. Afr. J. Aquat. Sci. 30 65-75.

VAN DAM, MERTENS A and SINKELDAM J (1994) A coded checklist and ecological indicator values of freshwater diatoms from the Netherlands. Neth. J. Aquat. Ecol. 28 (1) 177-133.

WATANABE T (1990) Numerical simulation of organic pollution in flowing waters. In: Encyclopaedia of Environmental Control Technology Vol. 4: Hazardous Waste Containment and Treatment. Gulf Publishing Company, Houston, Texas. 251-281.

WATANABE T, ASAI K and HOUKI A (1986) Numerical estimation of organic pollution of flowing waters by using the epilithic diatom assemblage - Diatom Assemblage Index (DIApo). Sci. Total Environ. 55 209-218.

ZELINKA M and MARVAN P (1961) Zur Präzisierung der biologischen Klassifikation der Reinheit fliessender Gewässer. Arch. Hydrobiol. 57 389-407. 
